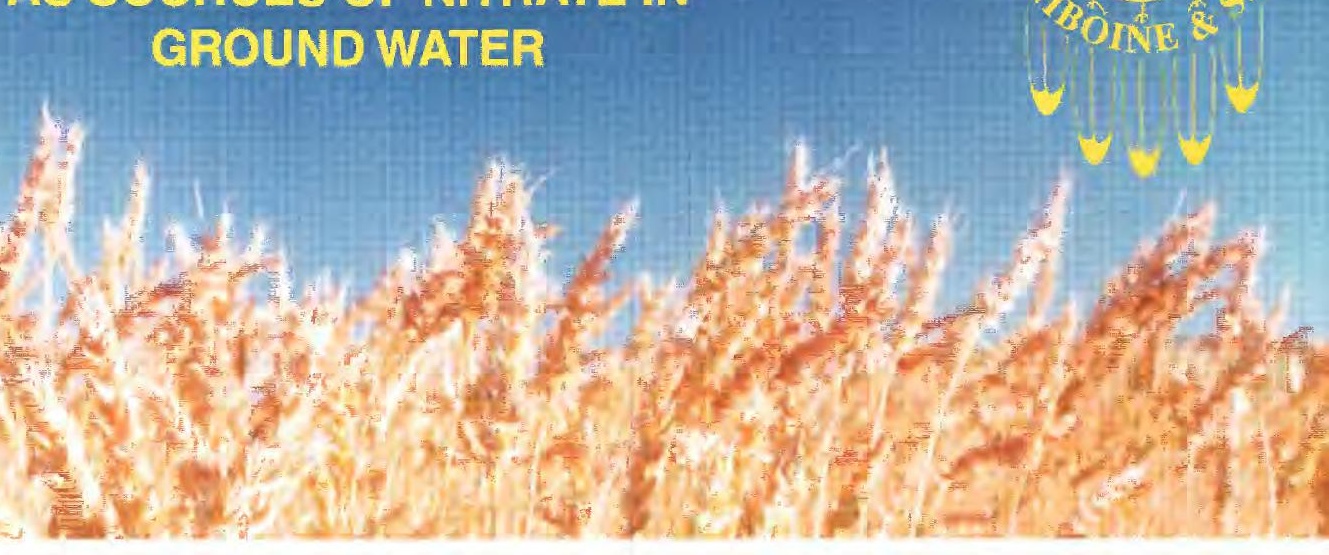

High levels of nitrate, which pose health threats, occur in shallow ground water in some areas where dryland farming is common. In these areas, the breakdown of crop stubble is a likely source of nitrate. Where wells are located near barnyards and feedlots, livestock wastes are a likely source. A case study in northeastern Montana defined the extent and sources of nitrate in ground water, and determined that changes in land use may affect nitrate levels in ground water in less than 30 years. Reductions in nitrate concentrations probably could be achieved through a variety of landmanagement strategies.

\section{SOURCES OF NITRATE}

Dryland farming and livestock production are possible sources of nitrate in ground water in some rural areas of the northern Great Plains of Montana, North and South Dakota, and Wyoming, as well as Alberta, and Saskatchewan, Canada. Rain and snowmelt that soak into the ground can carry nitrate from decomposing crop stubble and animal wastes to ground water. In some areas, movement of nitrate from the land surface to ground water has occurred in less than 30 years.

\section{Dryland Farming}

Dryland farming in semi-arid areas such as the northern Great Plains involves no irrigation and application of small amounts of fertilizer relative to irrigated farmland. To conserve moisture and

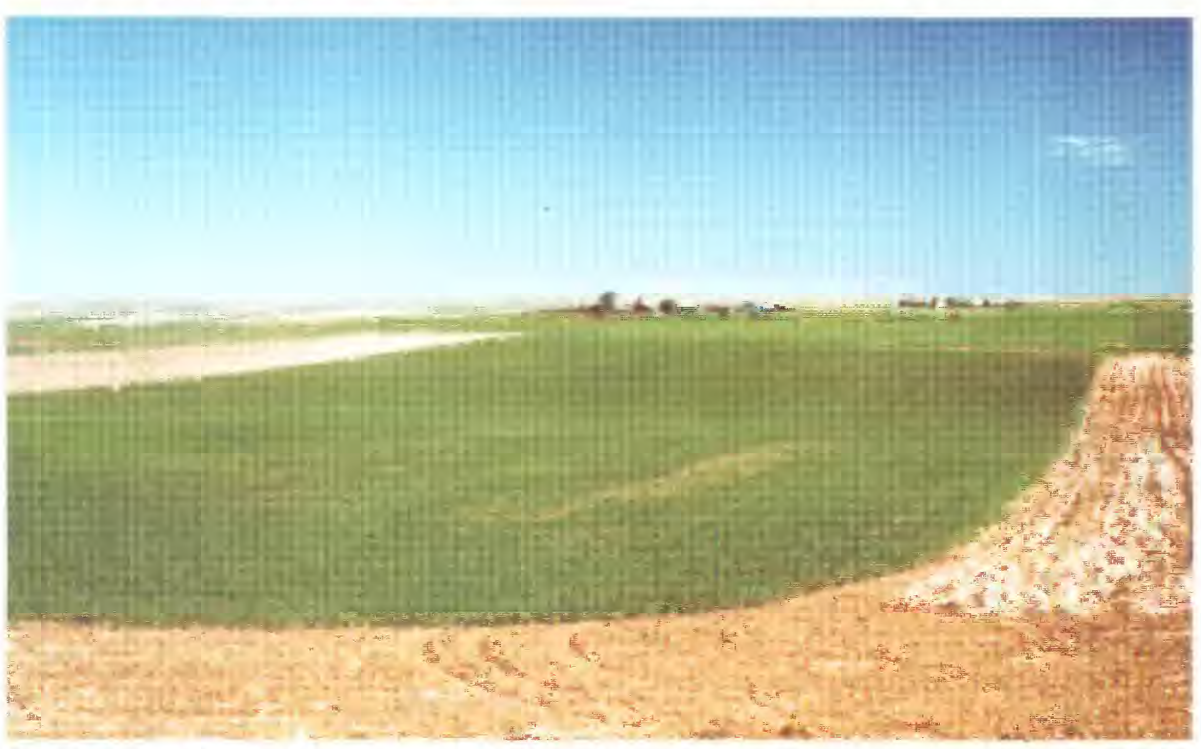

Cropland in strips of wheat (green) and fallow (brown). 


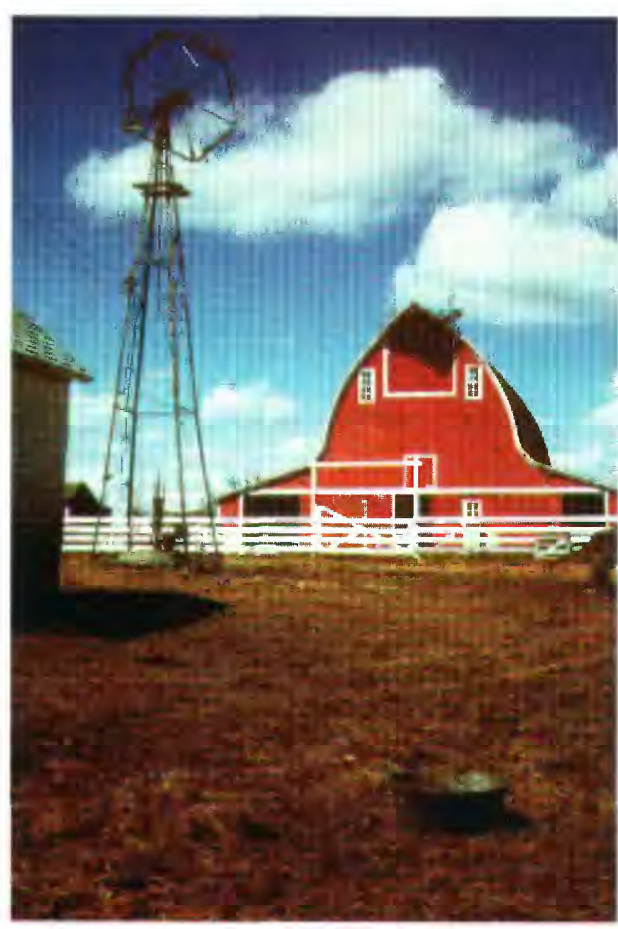

A typical water well located in a barnyard. water. Nitrate can be transported by rain and snowmelt that percolates through the wastes and infiltrates to ground water. Water wells commonly are located in or near these confined areas, and possibly tap ground water affected by this local nitrate-rich infiltration. In some circumstances, these wells may have no surface seal around the well casing, making it possible for livestock wastes to enter the ground water along the borehole around the outside of the casing. Therefore, the likelihood of finding nitrate in ground water can be high near livestock operations.

\section{HUMAN HEALTH EFFECTS OF NITRATE}

Nitrate is an inorganic chemical that can originate from many sources such as fertilizers, crop residues, animal and human wastes, soil, and subsurface rock. High levels of nitrate in drinking water (greater than 10 milligrams per liter ( $\mathrm{mg} / \mathrm{L})$ as nitrogen - the maximum contaminant level established by the U.S. Environmental Protection Agency for public drinking water supplies) pose health threats if consumed by humans. A well-known health threat to infants is methemoglobinemia (blue-baby syndrome) - a life-threatening illness that affects the ability of blood to carry oxygen. Recent research has suggested a possible nitrate-related health threat to persons of any age from non-Hodgkin's lymphoma-cancer of the lymphatic system. In addition, and in certain circumstances, nitrate in ground water can indicate the presence of other undesirable constituents, including fecal coliform bacteria and viruses.

\section{CASE STUDY: Flaxville and underlying aquifers, northeastern Montana}

A statewide sampling of domestic wells in Montana by Bauder and others (1993) indicated a close correlation between high levels of nitrate in ground water and dryland farming. One of the areas that appeared to have high nitrate levels in ground water is underlain by the Flaxville aquifer in the Fort Peck Indian Reservation, northeastern Montana. The Fort

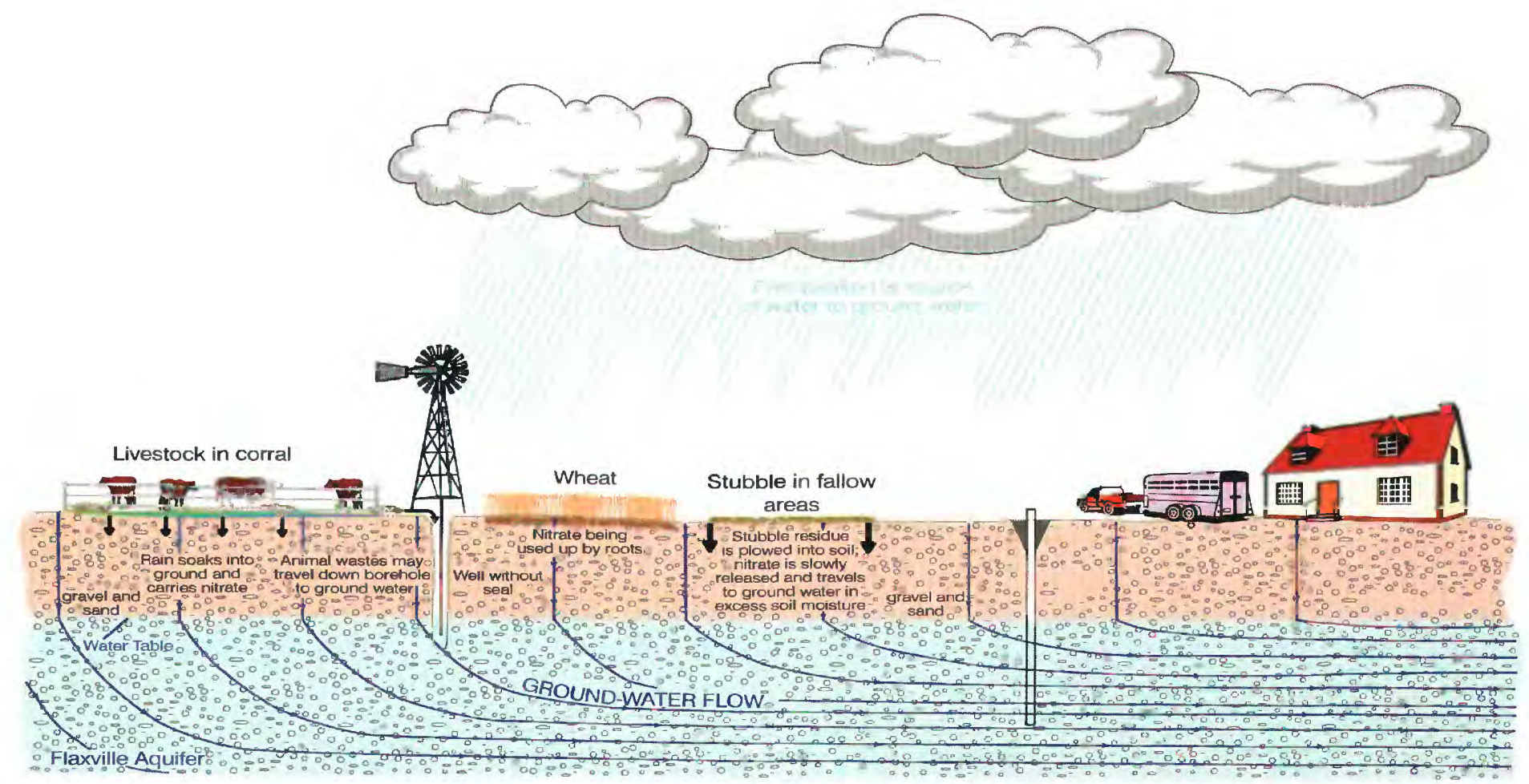




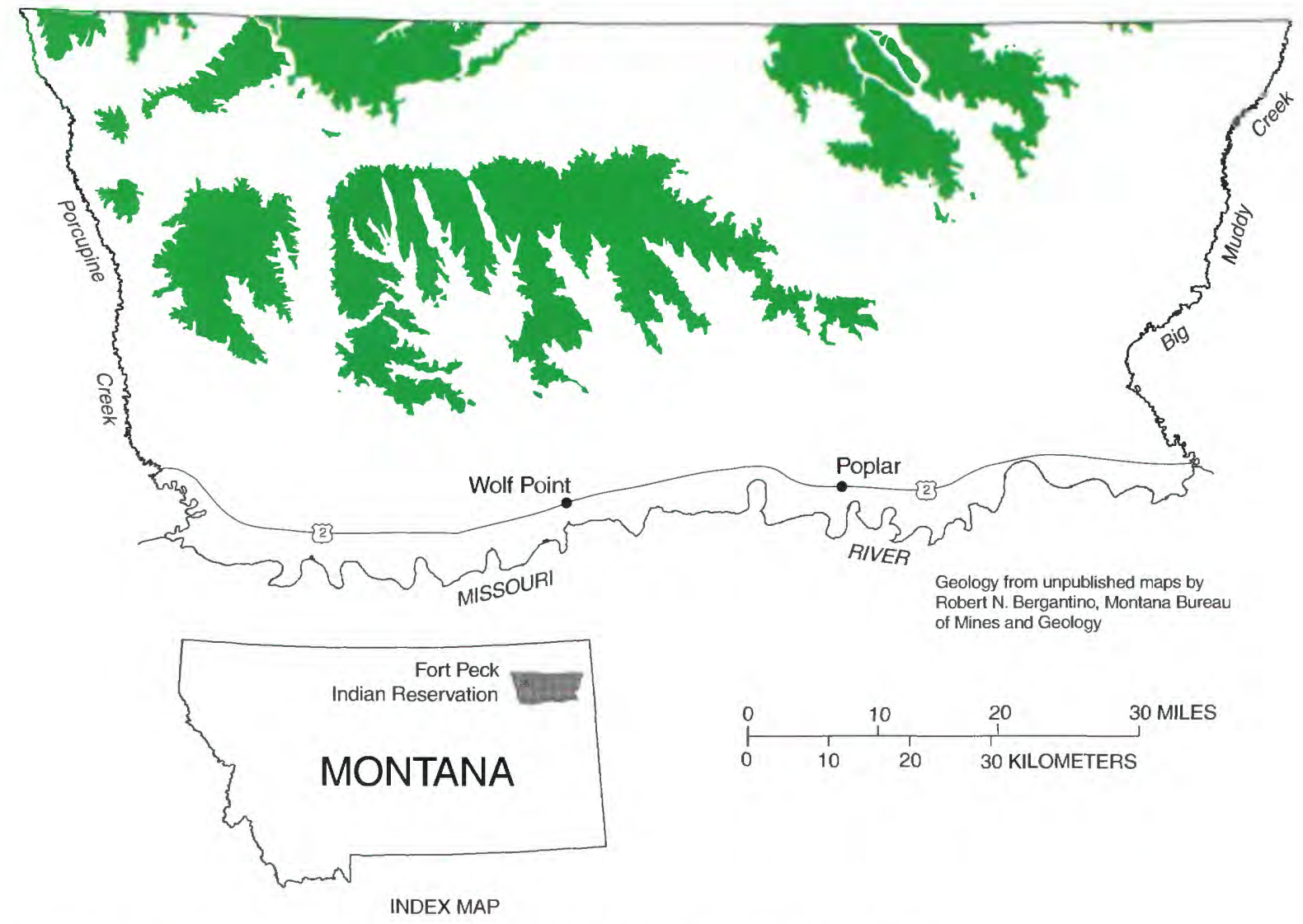

Flaxville Formation (green) in the Fort Peck Indian Reservation, northeastern Montana.

Peck Tribes and the U.S. Geological Survey (USGS), through a 3-year study, determined the extent and sources of nitrate in selected areas of the Flaxville and underlying aquifers (Nimick and Thamke, in press).

The USGS study found that nitrate was high (more than $10 \mathrm{mg} / \mathrm{L}$ ) in water from $84 \%$ of the 45 wells completed in the Flaxville aquifer and in water from more than half of all the 112 wells sampled. Most ground water in this area is less than 100 feet from the land surface, so the potential for land use to affect nitrate concentration in ground water is high.

Dryland wheat production using cropfallow rotation is the primary land use in the vicinity of the Flaxville aquifer. The other major land uses are native rangeland and land enrolled in the Conservation Reserve Program. More than half of the farms raise livestock. Herd sizes generally range from 30 to 100 cattle.

\section{USGS Research Results}

The effects of various land uses on nitrate concentrations in ground water were determined using two methods. First, the source of nitrate in ground water was determined using nitrogen isotopes.
Nitrate in ground water has different isotopic "signatures", depending on the source of nitrate. The nitrogen-isotope data for the study area indicate that the nitrate in ground water was derived from crop stubble and livestock waste. The data also indicate that fertilizer was not a direct source of nitrate in the water. Second, the date of recharge - when water from the land surface reaches the water table - was determined from the concentration of chloroffuorocarbons (man-made compounds used in refrigerators and air conditioners, also known as Freon) in the ground water. The higher the chlorofluorocarbon concentration in water, the more recently it reached the water table. This date can then be related to the land use at the time of recharge. Recharge dates indicate that nitrate levels in ground water have been affected by land use during the past 30 years.

The amount of land used for dryland farming was fairly constant between 1960 and 1990; however, the amount of that cropland that was fertilized has steadily increased since the mid-1950s. Although fertilizer does not appear to contribute nitrate directly to ground water in the study area, it probably increases the organic matter (roots and stubble) that can break down during the fallow period. The increased organic matter probably has caused, and may continue to cause, steadily increasing nitrate levels in the ground water. Livestock numbers have declined since the mid-1970s, so effects on nitrate concentrations from livestock wastes may decrease.

\section{STRATEGIES TO REDUCE NITRATE EXPOSURE}

Several strategies may reduce nitrate levels in ground water in areas where crop stubble or livestock are sources. In some areas, it may take less than 30 years for the strategies to affect the nitrate levels in ground water. These strategies are listed but are not prioritized.

\section{Strategies that may decrease the availability and deep movement of nitrate:}

1. Replace crop-fallow rotation with intensive crop systems, such as continuous crop and recrop, to use up nitrate in the soil;

2. Increase land area with perennial vegetative cover to reduce the amount of nitrate and moisture in soil; 
3. Decrease fertilizer use to reduce the amount of stubble residue;

4. Plant alfalfa or other deep-rooted crops to reduce deep movement of soil moisture;

\section{Strategies that may reduce} nitrate loading from livestock Additional Information areas:

5. Manage livestock to reduce nitrate loading to ground water;

6. Plug abandoned wells and seal unsealed or poorly sealed wells to prevent vertical leakage;

Strategies that may reduce nitrate exposure to humans from domestic well water:

7. Ensure new wells have adequate surface seals to prevent leakage;
8. Discontinue use of contaminated wells; and

9. Install treatment systems to remove njtrate from drinking water supplied by wells.

\section{About nitrate and human health----}

Walton, G., 1951, Survey of literature relating to infant methemoglobinemia due to nitrate-contaminated water: American Journal of Public Health, v. 41, p. 986996.

Ward. M.H., Mark, S.D., Cantor, K.P., Weisenburger, D.D., Correa-Villasenor, A., and Zahm, S.H., 1996, Drinking water nitrate and the risk of non-Hodgkin's lym-

phoma: Epidemiology, v. 7, no. 5 , p. $465-470$.
About dryland farming and livestock as nitrate sources----

Bauder J.W., Sinclair, K.N., and Lund, R.E., 1993, Physiographic and land use characteristics associated with nitratenitrogen in Montana groundwater: Journal of Environmental Quality, v. 22, p. 255-262.

Nimick, D.A., and Thamke, J.N., in press, Extent, magnitude, and sources of nitrate in the Flaxville and underlying aquifers, Fort Peck Indian Reservation, northeastern Montana: U.S. Geological Survey Water-Resources Investigations Report 98-4079, 45 p.

By Joanna N. Thamke and David A. Nimick

\section{Contacts}

\author{
Debi Madison \\ Office of Environmental Protection \\ Fort Peck Tribes \\ P.O. Box 1027 \\ Poplar, Montana 59255 \\ (406) 768-5155
}

Resource Conservationist

U.S. Department of Agriculture

Natural Resources Conservation Service

P.O. Box 1027

Poplar, Montana 59255

(406) 768-5155
U.S. Geological Survey Federal Building, Drawer 10076 301 S. Park Avenue Helena, Montana 59626-0076 (406) 441-1319 